\title{
THE VALUE OF YOGYAKARTA PALACE DANCES : RELEVANCE TO THE NATION CHARACTER NURTURING
}

\author{
Sunaryadi \\ Institut Seni Indonesia \\ Email: kabanram@yahoo.com
}

\section{Abstrak}

Tari Keraton Yogyakaria bukan sekedar tontonan tetapi adalab sebuab media yang mengandung tuntunan. Bukan hanya bagi semua yang terlibat dalam pementasan tari, tetapi juga tuntunan bagi yang menonton Patokan baku dalam tari keraton yang bersumber pada nilai tata krama keraton merupakan etika moralitas, sebagai sarana penanaman karakter. Nilai-nilai tersebut terumuskan dalam empat prinsip yang wajib dimiliki penari yaitu sawiji, greget, senggub, dan ora mingksh (falsafah Joged Mataram). Dikaji dari aspek aksiologis, tari keraton mengandung ajaran yang menempatkan 'rasa sebagai ruh' dan 'pengendalian diri sebagai inti'. Aspek rasa serta pengendalian diri inilah yang memiliki relevansi bagi pembangunan karakter bangsa saat ini.

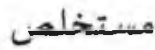

يوجياكارتا مشهد الرقص ولكنها ليست مجرد وسائل الإعلام التي تحتوي على إرشادات. ليس فةط. لجميع المشاركين في تنظيم الرقص. ولكن أيضا لتوجيه المؤشر القياسي مشاهدة القصر الرقص التي ترتفع في الأدب قيمة القصر هو الأخلاق الأخلاقية، كوريلة لزراءة حرف. وبرد وصف هذه القيم في أربعة مبادئ لتكون الراقصات المملوكة sawiji وهي sengguh ، greget، وأورا) mingkuh فلسفة ماتارام). درس من حيث إكسيولوجيا، قصر الرقص الذي بضم الذيم

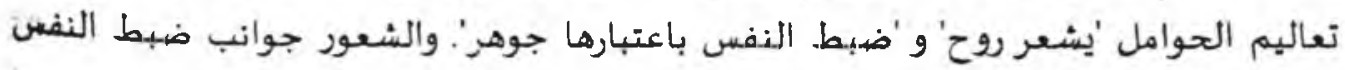
من هذه لها أهمية لتطوير الطابع الوطني هذه المرة.

Koyords: tari keraton, Joged Mataram, penanaman karakter. 


\section{A. Introduction}

Indonesian society now days has many colored multiple conflicts, demonstrations, religious conflict, the position seizure, and the seizure of property rights indigenous territories. Regrettably, all of them tend to be wild and brutal. Violence happens everywhere, attitudes of tepa slira are scarce, sincere attitude has been hard to find. Many cultural roots reflected in Pancasila has been abandoned, as if the nation has lost the identity and lost the spirit of the cultural life of the nation adhesive. The characteristic of Indonesia as a nation of virtuous and cultured, which emphasizes tolerance, mutual respect, mutual respect, becomes increasingly fading.

Javanese Pepeling (wise words) 'aja gumunan' which means do not get easily hypnotized by something new has been ignored again so that the glitzy foreign culture is accepted with the excessive admiration. Consequently there is no pride in cultural traditions, there is no desire to preserve and imitate them. Here the role of palace dances as a result of past culture which has high values is still needed, in order to build a human personality, of Javanese people in particular and Indonesian in general.

According to the Javanese value system, a good man is a human being who has the ability to balance his power of the mind and ego (thoughts and desires). The accountability in terms of mind that should not be forgotten is that a man should be sepi ing pamrih selfless (does not expect any return) in order to achieve the purpose of life to memayu bayuning bawana (creating prosperity, world peace), and to improve the welfare of the people which is based on the life harmony. One of the efforts to preserve the values that can be done through art is the development of palace dances.

The dances at the Sultan Palace are not only spectators but also media containing guidance. They are not only for those who are involved in the dances staging, but also guidance for the audience. Dissertation titled The V alue Of Yogyakarta Palace Dances: Relevance To The Nation Character Nurturing is a scientific study that aims to explore and introduce the noble values and the concept of living that accumulate in ethics and aesthetics of the palace dances. 
The benchmark for the palace dances that originated in the value of royal etiquette is the virtue ethics as a means of investment character, although exclusivity of the palace dances is often a dividing wall to transfer the values embodied in the dances to the public.

Basically the character of an art that is influenced by the soul of the era also reflects the soul of its creator. It is similar to the Sultan Palace dance created by Prince Mangkubumi (Sri Sultan Buwana 1). Mangkubumi's life experiences as a poor who came across the battlefields is the spirit that influences the patterns of thinking, leadership style, and his works. Dance works created are not simply as a sign that the dance was ever existed which is easily lost in time (living footprint in the sand of time), but it is an expression of the ideals and values of struggle of Hamengku Buwana I. Almost all of the dances he created were based on the concept of heroism and virtue kasatria. Through dance works that H.B. I expressed the view of life and the values it has espoused for his subjects implanted with the concept of animism dance known as the Sultan Palace Joged Mataram. According Soedarsono (1980: 24) dance palace is full of cultural education related to the value system and a system of symbols, because dance is a symbol of the load value. In other words, as a result of human creations, dance palace is a medium to communicate a set of values related to the problem of moral, social, and spiritual.

Dance palace does not only contain of a set of values in the form of a philosophy of life, but also a set of knowledge systems related to cultural patterns of people. Learning to dance is also learning ethics and morals, which requires discipline, perseverance, patience, peace, perseverance, and unyielding spirit. The questions are whether the values of the palace dances are still relevant to the nurturing of the character, as well as the extent to which the relevance of these values to the cultivation of national character? To answer these questions, it will be assessed through an understanding of the values embodied in the concept of bedhaya-srimpi and wayang wong, considering that bedhaya-srimpi contains of teaching values on life and living, while Joged Mataram is the way to perfection or life guidelines through its criteria. 
The research method used is descriptive qualitative approach that is not only historically factual, but also interdisciplinary. The method used for this research involves understanding the concepts, values, traits, and relationships among the elements in the dance palace. How do the values inherent in the palacedances that affect the lives of the palace, and its relevance to society today.

\section{B. Dimension Value Dance Palace}

As it is known, the dance palace as a show is not only related to aesthetic value, but also deals with moral and ethical values that are useful for the formation of character in nurturing a noble character. According Notonagoro (1971: 1), the value consists of:

A. Material value is all things that are useful for human physical life, or human bodily material needs. In the dance, the physical material can be equated with wiraga. A dancer is required to exercise the maximum motion according to standard rules that have been defined. Wiraga have achieved as much as possible to reach harmony with wirama.

B. Vital value is everything that is useful for people to be able to hold events or activities. In the dance, it is the same with wirama, for the material movement activities must be balanced to achieve harmony with the rhythm of the performance. Wirama is determined by the settings of the breath in the dance activities.

C. Spiritual value is useful for spiritual. In the dance, the spirit or appreciation is a union of wirasa, cipta (creation), rasa (feeling), and karsa (intention). Notonegoro divided this spiritual value into four types:

1. truth value, which is based on man's reason (ratio, cultivation, creation). In this case, a dancer must be able to run standard rules correctly and transform it in everyday life.

2. value of beauty, or aesthetic value, which is based on the element of willingness (esthetis, gevoel, taste). The value of beauty in dance is very complex, covering, motion, composition, makeup, fashion, quality of movement, music accompaniment, characters, and so on. 
3.virtue, or moral values, which is based on the element of volition (will, wollen, intention) man. Morale is a personal dignity which is reflected in the behavior of standard rules concerning moral ethics that should not be violated, and puppet stories containing values of truth, goodness become a life guidance in the attitude and behavior for the palace society, as individuals and as social beings.

4.reliyious value, is the absolute and highest spiritual value. It is based on the human's beliefs or convictions. Yogyakarta Palace Dances have always been associated with the presence of God as seen from the meaning of sawiji, and the symbols in the dance as shown in the symbol of bedbaya dance, both in terms of the choreography and the number of dancers.

Notonagoro recognized the division of these values (1955: 63) as a form of value that is objective, in which the existence does not depend on the perception of the observer. Notonagoro's division's value is the most suitable for the researcher since it corresponds to the basic concepts of Java philosophy of dance in the Yogyakarta Palace.

The results showed that from the axiology aspect, the palace dances have religious values, ethics, aesthetics, social, moral, and cultural which are influenced by Javanese culture, Hinduism and Islam. Value-religious spiritual or religious values (religious values) portrayed in the finding process of perfection in bedhaya-stimpi dance, that is from the beginning to the last appearance (since the sembaban to mundur betsa). Similarly, the ethical-social harmony (social values) spans the 'hicrarchy in the principles of respect and harmony, which affects the attitude of scif-control to avoid actions that could lead to conflict in a way that downplays the personal interests of harmony, and the balance is maintained.

In the dance world, the values as mentioned earlier are needed to raise the unity and cohesiveness among the dancers' movements with one another, in order to form a sense of unity among them. Motion displacement that accompanied the 'rasa (feel)' will be seen simultaneously, organized, flexible, fun, but the vice versa would disrupt the show, because it looks chaotic, irregular, and rough. Social Ethics, regards the understanding of the wisdom 
based on solidarity that leads to the consideration to behave according to moral rules, thereby it builds harmonious, sturdy, strong relationships in socializing. Dances for the palace society are means to convey ideas and values held as:

\section{Value of Ethic}

Ethics is a branch of philosophy that addresses the value of 'true' (right) or 'false' (wrong) in the sense of moral and immoral. Ethics in the Javanese minds are associated with good and bad. Javanese minds assume that the relationship between good and bad can be exceeded by increasing awareness. In Java the terminology of kadewasaning jiwa (self consciousness) is known as the soul or the maturity of the human spirit. Maturity level will form the character or characters that determine behavior or moral person, how a person must be a good human life.

Ethics in the dance can be seen from dance movement, because movement in dance interprets a particular meaning or significance. As a symbol, the motion can be interpreted with different interpretations according to the background of each audience. Therefore, the motion of the dance becomes a mean to understand the customs, culture, and social conditions of society supporters. There are two kinds of the dance's motion, those are 'motion of ethics' is merely the form of beauty motion without a special significance, and the 'motion of emic' multi-meaning (Kaelan, 2010: 15). Emic motion can be exemplified in the motion of sembahan, sila, ngenceng-encot, as well as some particular attitude or implies a certain value, which if only feasible to be implemented as forming character. Emic motion of the palace dances (Yogyakarta) can be seen from several patrap (motion) or positions, of which the motion:

\section{Sila}

Sila is the posture of sitting, body upright, legs crossed, hands in lap, motionless, concentrating hard to get peace, spiritual tranquility, which is done through good breath. Pull and regulated breath are done as smooth as possible in a state of quiet, anteng (calm), meneng, as if the blood flowing from toes up tc 
he center of the brain (the crown). In sila position that dancers are expected to lear thier mind from the daily routine to actually be in a state of quiet, empty / sumung (Endraswara, 2010: 172). At that moment a dancer should try to eneng / meneng / calm the mind, settles the mind (ening or ngeningake cipta) to concentrate, in order to think clearly, wening to reach the level enung (think over with the inner eye), and eling (aware) to perform dances well. At the time, the dancers should be able nyawriji, find God in him (her), and can reach the level of enong in which can find unseen signal from God that are still sinengker / winadi / still the secret of life. With God's grace, they can also concentrate (nyawiji) with the dance performed. The dancers are not allowed to see what was near or far as they are in a state of silence that they should try to look into 'inside', to the meaning of the dance (Holt, 2000: 123), in order to animate the dance.

\section{Nyembah/sembahan}

Starting a dance or before standing up to dance, usually the dancers preceded by the motion of sembaban/nyembah. Sembaban at the beginning of the dance, literally serves as a tribute to the king as the representative of God on earth, and as a respect to the guests in attendance. Inwardly sembaban directed to the Creator, as a prayer of salvation begged that his soul can be peace, clean (bening / wening) of the problems that may be encountered, for smooth performance.

Such an attitude is expressed in the Javanese word neng-ning-nang-nung (Endraswata, 2003: 95). Eneng-ening-enung presents in the heart or chest cavity as a Alavor (rasa sejati / true feeling). Enang means win, manage to beat their own desire and unify with the will to do. From the condition of silence it will achieve the maximum restraint, which Javanese calls it nur-rasa. Therefore, from 'sila' to 'sembaban' can be likened to a person who is doing meditation.

\section{Ngenceng-encot}

Ngenceng is synonymous with a state of tension, stiffness, while encot is a movement to find a balance gestures accompanied by the motion of mendhate (modestly, lowering the center of gravity of the body), so that the tension is 
even impressed as graceful, lithe authoritative. The power of Yogyakarta dance lies in its ability to balance the weight of the body in a certain position (on top of the pedestal one foot) with a slow motion / alus. The dancers must be able to move the body weight from one foot to the other. Therefore, the dancer should not be tense, but it also should not be relaxed (ora mingleub) to achieve an earthy quality (naive) but still graceful as typical dance of Yogyakarta Palace. The understanding to be able to be calm, not tense, and unable to resist the urge to create harmony through dance movement is very necessary in life. In real life ngenceng does not mean firmly on establishments that should not be tampered with, but it is more to kenceng (solid) on the principle of a fun crowd, which remains elastic for the mutual interest.

\section{Iguh}

Sultan Palace Dances, in addition to having standard or basic principles of motion, is also known as the specific principles that must be done in flexible (not rigid, there is no element of forced), worth (deserved, suitable), and a rehearsal or a clean, precise (Suryobrongto, 1981: 66). Therefore, the dancer must understand the sense of igub to cover their weakness in order to produce a luwes (fluid) motion.

Iguh is the way to achieve the desired effect, especially if the dance is danced in groups. Compactness should the first thing to do. Iguh in the dance means the ability to disguise the lack of the body that interfere with the perfection of the dance movement, for example, the dancers dashing short stature, small should be able to deal with the motion of ebrah (impressed manly / masculine). Igub is done as long as it reflects the attitude of graceful, graceful, dignified, cleanness and careful movements,). Igub also means the ability to adapt to all situations and conditions that would require seriousness and skills, because though sometimes it appears slow, the Sultan Palace dance changes the pattern of the floor quickly, either to male dance and female dance, especially in the battle scenes. Meaning that can be exemplified of the igub is that the dancers should be able to do ajur-ajer (adjust to all situations and environmental conditions), or empan papan (know how to position themselves), angon wektu 
(adjust the time), and angon rasa (more consider the feeling). This means that ethics should run on the basis consideration of the place, the precision of the time, and care for the taste or feeling. The lesson gained from this particular principle is that in life, one must be able to adjust the level of equilibrium with the surrounding circumstances, of course, in the sense of a favor.

\section{Banyu milli / mbanyu milli}

Banyu milli is like flowing water which is always moving, endlessly smooth in accordance with wiraga (all aspects of dance), wirama (compliance with gending rhythm / music), and wirasa (regarding to the feeling, 'content', or soul). All three must be united. Dance and music which are like a sentence is a punctuation; kenong, kempul, ketbuk are comma, while the gong is the point of physical gestures to the accompaniment of accuracy requires special experience to be able to move smoothly according to the structure of the music, and should be done in flexible or 'ngampub' (according to Suryobrongto's terms) that is slow but not too late or in a timely manner. The movement of banyu milli becomes a symbol of human life variant that should be able to adjust to the dynamics of life, not overbearing, not flow against the current which is the same as the understanding of empan papan and aja gumunan in Javanese. Someone who can adjust to the circumstances, and are not easily influenced by anything whose glitters is full of charm, his life will be calm and orderly water flowing. The studying of each position (patrap) used in the dance teach people how to control themselves, because they have to synchronize the movement of the eyes, neck, arms, hips, thighs, knees, legs, and fingers.

The ethics teaches people to be polite, orderly, through the understanding of eling to be responsible and respectful to others. That attitude is reflected in the dance in motion 'ndhadhap' and 'laku dhodhok'. Ndhadhap in everyday life is done when young people have to go through the seating of older people, by slight bow of respect. It is an attitude of respect and decency that is now being abandoned because it was considered as feudalism, did not keep pace with the times, so that there remains only a gesture to show equivalence between the neighbors, which sometimes exceed the free norms of 
politeness. It can be said that learning how to dance is learning about the propriety of conduct and behave. The understanding includes the educational sense, including in controlling feelings to avoid conflict or hostility. The forms of suba-sita (manners) in dance is also seen in the pocapan or antawecana (dialog) using unggab-unggub (level of ngoko karma madyo, krama alus) or by using a basa bagongan (special language used in the palace, or to the dialogue of the gods, depending on the needs of the content of the story).

\section{Aesthetic Value}

The word 'dance' in relation to dance palace, at least refers to two terms of the art of dance as part of the performing arts and the dance which means the art movement by humans or dancers. Since the pre-history era the data of the dance and the dancer have been found in some metal objects, nekara, or bronze ax. A number of the object paintings describes the figure of men who were dancing. Some are wearing masks, others are wearing headdress in the form of long feathers. The long history of the existence of Javanese dance is shown by the historical data as the data in the form of literary inscription, Kakawin, as well as the data in the form of art reliefs showing the presence of the people who were dancing and playing music. Kakawin data telis dances including the Arjuna Kakawin Wiwaha, Sumanasantaka, and Negarakertagama. Data art can be seen in relief Prambanan and Borobudur contained dance scene with Hindu-Buddhist influences in Javanese dance (Sedyawati, 1981: 164). From these data it can be seen descriptions of the performing arts, the type of show, the name of the dance, musical instrument accompaniment, and some work related to the performing arts.

The aesthetic strength of the Javanese traditional dance lies in the feeling. Feeling and controlled breathing system (like Yoga breathing), are Hinduism aesthetic principles that remain growing in the Javanese palaces today. The sense of the palace dances is the driving motor to express the characters, so there are senses of alus, feeling manly, lurub (smooth, quiet), lanyap or mbranyak (subtle but dynamic). The correspondence between a sense and the artistic expression is a prerequisite to achieve the power of dance, 
which can evoke a sense of unity, a sense of togetherness, and mutual understanding. In broad terms, it can lead to a sense of nationalism associated with the cultural treasures of the nation. Thus, the aesthetics of dance is a reflection of self control, because everything is made to an individual or group.

The acsthetics sensory of palace dances can be seen from the aesthetic movement, makeup, and clothing. The aesthetics of the palace dances cannot be scparated from the existing taw motion, the motion consists of cstablishment neck, torso, thighs, legs, arms, adapted to the character of each dance. The aesthetic term of each motion is different between the alus motion of the female dancers and the male dancer. Similarly, the makeup and the clothes worn are according to provisions of each dance.

\section{E. Moral Value}

Moral value is the value to be an ethical decision, which can be used to make choices wisely in everyday life (Palmquist, 2002: 292). One issue would be an ethical issue if the decision involves a choice among several values that are directly linked to the basic moral principle of humanity (Zubair, 1987: 71). Basic moral rules include the rules that serve the good of the basic principles of the act, that man shall do the good ones and avoid the bad ones. Second, the rules of justice are the principles that lead to the implementation of a value function to ensure that no one is deprived of their rights for the others' benefit (MagnisSuseno, 1988:132).

The palace dances become the foundation of critical thinking about moral teachings, which reflected the value of philosophy, range of motion, accompaniment, and the meaning of dressing exemplary fashion to form a virtuous man. Therefore, many parents (in the kingdom) take their children to leam to dance in the palace in order to get the lessons of ethics and morals, which are beneficial to facilitate relationships between individuals and between groups within society.

Related to the moral problems, Hamengku Buwana I's dance was a dance with a philosophy of Javanese cultural values. Practicing dance at the palace is not only a training of the skill and flexibility or stretching, but it is also 
the basis of physical and moral education. The physical education can be seen from the ethics of the moving body, worn fashion, ethical behavior in the play, as well as the subtlety souls to be processed according to the motion and rhythm of gending. The dancers are required to adjust to the rhythm of gending, sometimes to display a quiet, soft, hard, or seseg (fast) atmosphere. Sensitivity to the music itself will also affect the attitudes and acts in following the rhythm of life. It is sometimes hard, surprising, and sometimes fun, reassuring. It can be said that it is an attempt to attach a decent life through the existing rules in the classical dance style of Yogyakarta.

The standard rule or pathokan patbokan baku - called paugeran, of the motion arrangement variety to the dance form is taught with strict discipline concerning:

1. Wiraga or dance movement should be pacak (beautiful). This movement is centered on cetbik or joints between the tights and body. To maintain the balance of the body should be in a position mendbak (down). This movement requires special training to familiarize unjal napas (breathing), then released simultaneously with the release of tension, and arranged so as not to change the attitude of the body. This movement is actually a physical education and sport inner sense, so people can take advantage of the good, and if it is required then the iklas (Legawa) being lowered, in order to establish balance and harmony of life with others.

2. Polatan or pasemon (face expression). In this case, the eye will show the authority that express the soul of the character. The eyes will show the pasemon expressing a various feelings of anger, joy, sadness, love, upset, and so on. Pasemon will control the emotion softly but touch the audiences' feeling. In other words, anger, joy, sadness and other feelings must be shown to the soul in a controlled way or alus (Soeryobrongto, 1982: 21). Feeling happy or excited cannot be expressed with a smile, but emanated from his soul, so the mood was seen from the face or pasemon.

The lesson can be taken from it I that it is important for having self control in the social interaction, that any problem cannot be solved violendy, 
emotionally, but it can be overcome with tajem (stunningly) manner, Jatmika manner (any behavior based on rules of decency). This attitude will foster awe, respect, and prestige that arouse sympathy or trust, as well as it shows beautiful and subtle understanding, in the sense of self-control. Various provisions of the standard should be taken seriously by the dancers, so they inherent it in their actions. They do the motion that will be looked supple, pleasing to the eyes, their attitude becomes regular fun, which is expected to be carried on in association with the environment.

The ideal man for the Javanese community are capable of behaving and acting in accordance with the norms characteristic of refined, polite, quiet, civilized, and friendly (Geertz, 1976: 32). In terms of training the mind, the teaching that is meant here is the doctrine of good behavior, true greatness of soul, and honesty that can be internalized through the goodness of the characters in the puppet. Exemplary figures puppet is an inspiration in everyday life. The dance at the palace becomes a guidance and control to the human behavior in society, because it is also a medium to understand how people construct their world in everyday life, using the social values of its culture through a dance work. Therefore, the dance, in addition to use it as a symbol of the greatness, is also used as a means of education for the sons and daughters of kings and other royal relatives.

\section{F. Social Value}

The education of Javanese character emphasis on the people unity. The realization that he is part of the 'neighbor' requires him to be able to create a sense of 'karyenak tyasing sasama' (making others comfortable). The unity within a group or society can be raised through the value of harmony, compassion, tolerance and mutual assistance. These values span in the hierarchy of Javanese culture in words bamangku (generous and true to his words / sabda pandhita ratu), bamengk $u$ (protective and being fair), and bamangkoni (responsible for the actions and decisions taken).

Among the dancers, the compactness is the main requirement for the achievement of the unity movement among the dancers, so the presentation 
looks unison, regularly. This work requires self-control to not accentuate egos, mutual respect, tolerance, and mutual support. Sense of togetherness, unity, and tolerance, not to disparage others (giri lusi janma tan kena kinira) is still required in the association live wherever humans are. Here we see that the cultivation of character and noble character is needed to offset global competition and strengthen the identity to strengthen the national security.

The dance also teaches love to the nation that arises out of a sernse of togetherness, love to neighbor because of the proximity of each other in a dance exercise, and respect for teachers and parents. When people dance, their souls merge into one entity even though physically they dance on their own. Each dancer is no longer thinking about the existence individual, but concentrating to keep the unity of the dance. Each dancer does not expect that there is a deviation by one of the dancers for the importance of individual (ego), but should be ngemong supporting each other. All the dancers are obliged to keep angon ulat (caring of each other). The dancers' 2wareness of their own role is understood as a liability and should be implemented in earnest. The seriousness of the duty of the dancing is not affected by its position as a leading role or a supporting role. Even the supporting role still has the responsibility to forge the unity. Those things are realized and understood together as in the concept of one person dance error would be devastating to all.

In this regard, Bakker said that the unity of culture (in this case: dance) reflects the integration of the man himself (dancer). The unity must be continued to fight through the structure and configuration. The structure is the union of the dance interdependent elements leading to a common goal (to appreciation or spirit dance), while the configuration is the particular order of the various manifestations of culture (the rules of the dance), thus it forms a standard pattern (Bakker, 1984: 83).

\section{G. Religious values}

The palace dances were originally a sacred work of art, because it contains the philosophy of life. Prince Suryobrongto gave an example that bedhaya is a sacred dance which is full of the svmbols of life, because the dance 
is nor just a movement, but it is the action that is displayed and the reference alive.

Sultan Palace Dances has the philosophy summarized in the teaching of ngelmu sangkan paran and the philosophy of Joged Mataram. Ngelmu sangkan paran is set forth in the form of translucent magical ritual dance - srimpi bedhaya. Sangkan paran provides guidelines which includes three things: first regarding to the awareness that human beings come from God (urip iki saka sapa), second, regarding to the duties and obligations of human beings in the world (urip iki arep apa), and third, dealing with the return of man to his Lord (urip iki pungkasane piye). Therefore, in the context of ethics, the purpose of human life is manunggaling subjects to Gusti, and in the realm of aesthetics Javanese believe that goodness and beauty are the manifestations of the Essence of the Most Holy God.

K.P.H. Brongtodiningrai - a master of Yogyakarta dance since the reign of Sultan Buwana VII, Buwana Hamengku VIII until the middle reign of Sultan Hamengku Buwana IX - interpreted that the formation of bedhaya describes the human spiritual journey from the purwa (early), madya (who lived in the real world), wasana (as the perfect man or a perfect human being), which sometimes must face the dilemma between the desire of logic and spiritual needs.

Bedbaya is danced by nine dancers. Human physical dimension includes nine holes were found on the body wadag, as a microcosm of the symbol of jagading manungsa consisting of two eyes, two nostrils, two ear holes, mouth, dhubur (anus), and genitalia. In the world of puppetry, the organ of the human body is often referred to babahan hawa sarga. When one wishes to achieve something by meditation, meditate, mesubudi getting closer to God, then he should be able to pati rasa (concentrate to The One), and pati raga closing nine holes which are the source of all passions (amarah, lauamah, supiab). That means he should be able to overcome the temptation that comes from vision, hearing, smell, mouth / taste, sex and lust.

Judging from the composition, bedhaya dance consists of several formations called ' rakit'. If we look closely, it turns out that some changes in the composition can be grouped into rakit lajur, rakit ajeng-ajengan, rakit iring- 
iringan, rakit tiga-tiga which are repeated several times depending on the needs or the theme of the dance, then just get to the core plot on the composition of rakit gelar.

Bedbaya formation of entering the dancing stage and of exiting the dancing stage, uses the form of composition ' rakit lajur' which describes the physical man from head to foot, with five dancers in the middle (endhel pajeg, batak, jangga, dhadha, bunthil), and four dancers in left-right (apit ngajeng, apit wingking, endbel wedalan ngajeng, and endhel wedalan wingking). Thus the lajur composition consists numbers of four and five. According to Javanese cosmology quaternion representing the notion of keblat papat or four cardinal directions that limit the universe, namely the east, south, west, and north. Keblat papat in the sense of Javanese culture covers a number that is in the middle as a principal or pancer (keblat papat lima pancer). The position of the dancers in the middle as pancer shows that humans have an important role in maintaining the harmony of the cosmos, or otherwise it will lead to chaos. The realization of harmony or order is determined by human morality. Universe will serene, peaceful, because of the role and actions of human beings as 'center', instead the disaster and misery are also the result of human thought.

Besides having an understanding of keblat papat, it also includes the notion of the existence of sedulur papat or kadang papat (f our brothers born with baby, such as amniotic fluid, blood, placenta, and umbilical cord). Sedulur papat is believed to affect the extension of individual identity of each person. However, in relation to the philosophy of numbers five and four on bedhaya dance, Brongtodiningrat more inclined to the notion that there are five mudah, with four elements that is a picture of the (human origin) or asaling dumadi. Asaling manungsa begins with the existence of the nature of the $d z a t$ then with its nature, they affect each other in having the life. The perfect new life after being fitted with the five life elements or five mudab, which consists of the rob (soul), nur (light), rahsa (feel), budi (personality), and napsu (lust), which is derived from the four elements or the four powers of the water, fire, wind, and earth or soil.

The perfection of life to manunggaling kawula-Gusti is the essence purpose of Javanese people. The journey of human life to return to Him is certainly not 
smooth, but is full of obstacles or certain intrigue. Various obstacles of life was described by the battle between the dancers of batak and endhel which are sometimes out of the formation, as a symbol of discrepancy between the will (feel/spiritual) and logic (mind/worldly) that often occur in human's lives. Similarly, the exit and entry of 'apit to the formation 'lajur' become a symbol of the human mood of instability.

The picture of man's inner doubts (based on the conscience) in making the decision between choosing the good, less good, or even better is visualized in the formation of 'rakit ajeng-ajengan' (line of sight between the batak and endhel). If the good is taken, then the world will be peaceful and reach jumbubing kawula lan Gusti, but if the bad is taken the world will be broken. The choice is a risk that must be justified morally. The formation of 'rakit ajeng-ajengan' (three dancers on the left, six dancers on the right to the position of the two mainl dancers : endhel pajeg as a reflection of the heart / mind, and batak that represents head / thoughts in the position of facing each other), to the formation of 'rakit iring-iringan' is a contradiction description of logic and feeling applied subtly, gently, in accordance with the Javanese virtue ethics. Conflicts between batak and endhel is not disclosed loud, rough, with the position of arguing, but it is communicated in a form of dynamic, harmony and harmonious motion of dialogue, (Maharsiwara, 2007:102). The final battle shows that the battle between emotions with the fecling must be ended with the reunion as loro-loroning atunggal. It means that both the nature of the conflict should always be sought in early stages of the balance. The ethical value contained in the formation of rakit ajeng-ajengan and iring-iringan is the element of 'mawas diri' (introspection) as well as the ability to 'curb the passions' compliance with existing norms. Various lust or desire must be controlled in accordance with the logic, because the true happiness is obtained when the brain and heart are established a unified mind.

In his life journey, man must pass three levels of baitul makmur, baitul mukharam, dan baitul muqadas, which are in the language of puppet (according to Hindu ideology) called 'triloka'. In bedhaya, it is spelled out in the formation of rakit tiga-tiga. Formation is a manifestation of the mind in which has three 
strengths or 'tripusara' that comes from the brain, heart, and abdominal cavity. All the three have to nyawiji, united into a symbol of telu-teluning atunggal or Trimurti (water, fire, wind) that will produce pramana (strength). Water (sarining toya) produces physical spirit, conscience, plant spirit and animal spirits. Air (swasana) or wind, produces napas (breath), ampas (bad breath or air or wind), tanapas (irregular breathing), and nupus (without breath. Fire (bagaskara or sun) produces patang perkara of lust (four lust) the passion of amarab (anger), lawwamab (appetite), supiah (cannot control themselves), and mutmainab (goodness).

Three powers produced, originating from three natural worlds or triloka that are nature of janaloka or alam wadag (ephemeral nature) form of the body in where all temptation and desire are. Second, alam guruloka (feeling) brings rasa sejati of joy, satisfaction, loyalty, and so on. Third, alam indraloka (the mind) is the abode of creativity, initiative, and wishful thinking. That is the translation of 'rakit tiga-tiga' that man has to go through three levels, three worlds, or three nature related to triloka or tribawana in his life that is the world center of the live human body or physic or wadhag, over the world of the true God, as well as the underworld of human beings who are not good in their life (dur angleara). In other words, the composition of rakit tiga-tiga shows the Javanese living teaching which thinks that the world with all the living things should be united in harmony and balance between the physical and spiritual needs in order to achieve a safe life.

To achieve perfection, in Islamic way people must pass four stages of sembah raga (sarengat) or clean themselves physically (physical nature) resulting order or rules. The second is sembab cipta (tariqat/ syariat) which is achieved by puring the heart. This behavior produces action. The third is sembab jiwa (bakekat) which is the inner attitude to nurture the spiritual life in order to achieve life perfection. The fourth is sembab rasa (makrifat) which is the behavior to achieve rasa sejati to realize that everything that happens in this world is a kasunyatan / unavoidable reality. Those four learnings are reflected in bedbaya dance composition of the four dancers' frame apit ngajeng, apit wingking, endhel wedalan ngajeng and endhel wedalan wingking (Brongtodiningrat, 1981: 18). The understanding of kasunyatan creates a feeling of resignation / sumarab to the 
power of Almighty God. Therefore, the people will know the true essence of life since the struggle has come to the core story. This stage is represented in the composition of the 'rakit gelar' in which humans live reap the fruits of thier behavior to achieve an understanding of jumbubing kanula-Gusti or curiga manjing warongko. In rakit gelar, the story content is visible. The vocal chant/song or tembang further clarifies and facilitates the audience to understand the story. The various changes in the composition of bedhaya dance show a process marked by the turmoil of life, sometimes hesitant, sometimes have to go back to the choice that has ever been taken, before finally determine the determination.

Given the significance contained in bedhaya dance makes this dance as one of the palace dances as having special status. Bedhaya is a representation right of Sultan (as lelangen dalem) which should only be performed on the permit, at a particular time and place that is considered sacred. Therefore, bethaya is a symbol of supreme authority in the palace which symbolically describes the spiritual connection between the sultan with the universe, or the relationship between the powers writh the cosmology.

\section{H. The Philosophy of Joged Mataram as a Basic of Palace Dances}

During this time, the philosophy of dance called Joged Mataram consists of the concepts of sawiji, greget, sengguh, dan ora iningkub which are only applied as a foundation for all dances in the Yogyakarta Palace. However, based on the results of the author's study, Joged Mataram turned out to be the cote teachings of Ki Ageng Sela who lived at the time of Demak cra (XIV century). Ki Ageng Sela's pepali was rewritten in the form of Serat Madu Tata Krami by Kyai AbduJ Zalil in 1830, as a gift to Sultan Hamengku Buwana VI. Ki Ageng Sela's teaching proves that the concept sawiji, greged, sengguh, ora mingkub has played ar important tole in the life of Javanese people since many years ago, it's just nor implemented in the form of dance.

\section{Sawriji}

The word sawiji comes from the word Siji which means one or mort 'united state'. Sawriji in the dance is reflected in nyembab movement which is dont 
at the beginning of the dance. By the time a dancer began to concentrate away from the things that had nothing to do with the target concentration for the truly determined nyawiji with dance that will be performed. G.B.P.H. Suryobrongto interprets the meaning sawiji as a concentration on the ability to unite the will, attitude, to mobilize all the spiritual strength and mind toward clear goals, and do so on an ongoing basis (Suryobrongto, 1981: 90). To achieve sawiji a dancer must rely on motion control and character. It means a dancer must be able to establish the correspondence between the meaning of the dance, the type and range of motion, and the music, which is supported by the correct use of clothing, because clothing also serves to strengthen the character of the dance. Sawiji in the context of the philosophy of the dance is the perception of the three components that must be integrated to form a harmonious unity between gestures, people (characters), and the role that is delivered.

According to Ki Ageng Sela, sawiji in daily life is as stated in the stanzas of Dhandhanggula (pp.D, b.30, p.9) at Serat Madu Tata Krami :

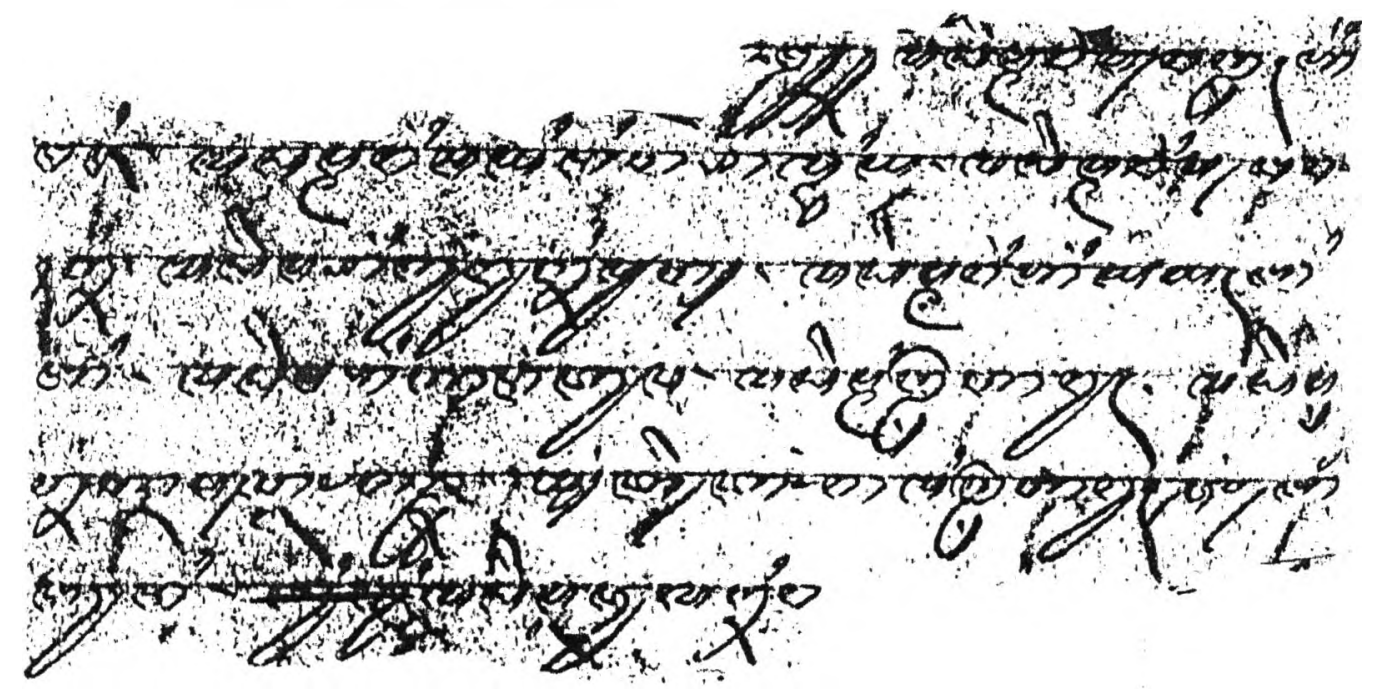

myang tetangga mintra karuh wong berbudi;

madhep kawulanira. 
Meaning steady devote to the king; devote to the Prophets; devote to God; devote to teachers; serve mother and father; serve elder brother; serve (well, politely) the partner; serve (respect) to relatives and friends, as well as virtuous to neighbors; respect for

\section{Greged}

Greged in Javanese means spirit or passion. In dancing, dancers must do every movernent seriously, earnestly and eagerly, not just move as they wish to. To produce the expected movements, each dancer must have the power of motion, or strength. Strength is not only limited to physical strength, but also to the ability of the dancer in giving the 'spirit' of the dance.

Male and female dancers require different power. Joged gagah and Joged alus also use different power. Suryobrongto said that the spirit should not be abondoned, but must be restrained to fit the character of the dance. It means that a dancer must be restrained emotion. Greged as 'motion character' is the result of emotional control that is expressed through a dynamic sense of movement or motion control. If it can be achieved, it may be said that between the dancer and the dance have melted into a single unit or had nyawiji.

Greged often arise because of talent or of training and experience. Greged is the desire of every human being in the form of lust, ambition and passion. Without passion, man is not creative, less effort, less active, and not eager to work. Greged presence will encourage someone to meet individual needs as a burning desire will generate a new passion in life.

In the writing script of Madu Tata Krami by Abdul Zalil quoted the teaching of Kyai Abdul Rahman (Ki Ageng Sela), greged is expressed as:

$$
\text { ... Atrangginas rumêgsaning dadi... at }]=\text { gins } \mathrm{R} \text { (megSni=ffi... }
$$

Meaning: capable to keep the success (in the action) and high spirit (greged) will produce good results. (Abdul Zalil, 1830. Pp.. D, b.26.p.8)

\section{Sengguh}

According to Suryobrongto, senggub is self-confidence, but it does not mean 1 be arrogant. Dancers must have confidence that the technique and the so 
have been mastered well, so they are able to perform it maximally. The confidence is nurturing mental toughness aspect when dancers perform in order to attain the level of munggub (well-established) and tanggub (steady). Thus, the meaning of self-confidence is the ability to motivate themself and manage the emotions, to express the character and soul of dance well.

Senggub must be based on the science : the science of truth and honesty. Therefore, confidence is closely connected with the principle or idealism. Senggub is also needed in daily life due to having a sense of senggub positively, then others will respect and appreciate.

$\mathrm{Ki}$ Ageng Sela found senggub should be applied properly in certain circumstances, as it is written in pupub Dandhanggula 21 following stanzas:

is_guhai $=[\mathrm{w}=\mathrm{ok}=\mathrm{me} / \mathrm{ktbufi}$,

s_guhb $[\mathrm{rsHi}=\mathrm{k}=$ teptkn $\backslash$,

s_guhb/rsWicr[n,

s_guhtengluruh,

s_guhmnisP]kHti,

s_guhrgkern,

s_guhbistuau,

s_guhtberigegul $=$,

s_guhttans_guhkysnÒ|i,

s_guhky[w=okumP].

Sengguh ing wong kang merkata budi,

sengguh bares ingkeang tepatahan,

senggub bares wicarane,

senggub tenaga luruh,

sengguh ulat manis prak, ati,

senggub raga kerana,

senggub bisa tuhu,

senggub taberi gegulang,

sengguh tata ana senggub kaya santri

senggub kaya wong kumpra.(Abdul Zalil, Sela,1830.pp.D. b.21) 
Meaning: senggub in people who are virtuous, senggub (is) friendly (in the relationship), senggub is honest in saying, senggub is subtle, senggub is interesting sweet face, senggub is strong body, sengguh is really doable, senggub is diligently learning (practice), senggub (is) has order, senggub is a students, senggub likes a sudra.

Furthermore, it is mentioned in tembang / song that senggub should be based on a sense of sincere and concern the behavior that the heart remains pure, not arogant

\section{Ora mingkuh}

...jêjêr jêjaluk jatine... (mempunyai rasa percaya diri yang tinggi dan benar-benar teguh pada pendiriannya (Abdul Zalil, 1830. PF.. A, b.11)

Meaning : Expect the truth, be honest so honored, really straight to the establishment.

The attitude of ora mingkub in the dance is the determination to play its role, which means is able to habdle any situation. In healthy or sickness, dancers must keep their duties. Ora mingkuh in the philosophy of Joged Mataram is the last level with three interrelated previous teachings (samiji, greget, stnggub). If dancers have not mastered the three levels, it can be said that they does not have enough experience in the dance because they have not mastered the nature and character of the dance and it makes them difficult have the confidence to carry it. Dancers must bangabebi, not only mastering the technic, but also understanding the nature of the character of the dance that was delivered. It is clear that the four elements of the philosophy of Joged Mataram (samiji greget, sengguh, ora mingleub) are the four basic elements that must be occupied, so the dance has the 'soul'.

If philosophy of Joged Mataram is broken down into several sections, it will be seen its significance for the wider community. The descriptions of some pepeling above give a true insight and understanding of the source and origin of Joged Mataram which is actually the implementation of Ki Ageng Sela's pepali as recorded in Serat Madu Tata Krami. 


\section{Relevance Philosophy of Joged Mataram For Nurturing Character}

In Javanese point of view, the meaning of samiji in Joged Mataram's philosophy, is a manifestation of the determination embroidery, beleif to manembah (devote) to God because it is believed that all human effort can only happen on His willingness. Sawiji to God and His teachings makes man always careful to act, speak and behave. Thus, it will grow tolerant attitude towards the safety and prosperity, with a clean heart, introspective, and always mindful lan alert so that they align the words with the action, makes humans empathize and sympathize each other for the mutual interests.

Sawiji means concentrating on the intention to lead oneself with the spirit and sense of responsibility of trying to suppress the lust to serve others and his country. Sawiji concept is not only individual's action-oriented but also the social system as shown in the attitude of mutual cooperation. It is the mutual cooperation of all citizens as an integral member of the community which extends to the one unity as a nation within a nation. Through sawiji or nyawiji, it is expected that humans createz a sense of golong-gilig saiyeg-saeka kapti (unite the goals) as the only word and action in order to maintain the harmony of living together. Sawiji in social life will cause a sense of melu bandarbeni, compulsory bangrungkebi and mulat sarira bangrasa wani, so human can be fair, prudent in making decisions (Endraswara, 2010: 173).

Greged is like the sun that burns the spirit of the source of power to run the dynamics of life according to their respective capabilities. The spirit of burning also means a commitment to pursue and realize expectations by working hard and to be able to solve problems (mrantasi gawe). However, it should be awared that excessive zeal will make people forget themselves, and eventually will move uncontrollable desires (pepinginan). Thus, greged must be routed and executed with calm, patient, calculating not grusab-grusub or carclessly.

The implementation of senggub in everyday life is synonymous with confidence. The confident of Java ethic should be based on the doctrine of selfcontrol or not promote ego, do not be arrogant. Confident in this matter implies 'aja golek menange dewe' (do not seek to win themselves) considering 
himself the best, most true one. People who are confident, does not serve the lusts of flaunt status, intelligence, and power (aja ngumbar napsu, adigang, altigung, adiguna), but with that belief people are dare to budge (wani ngalab) for a more noble purpose. People who can put sengguh in the correct proportions, not arrogant / conceited (ora deksura) will be respected, even become role models. Those people lives orderly, organized, and often andhap asor, believing that God gives something more, to be distributed to others. Thus, the question of confidence is the ability to motivate themselves and manage emotions is necessary to establish a truth, goodness, and virtue.

The attitude of ora mingkuh is determination which means being able to face any situation. Ora mingleub also means steadfastness in its ability as a form of full responsibility for what has been promised. People who have a firm stance (ora mingkub) can usually be trusted because of the harmony between words and deeds. People who ora mingkub are not easily being influenced and able to be protective for daring to upholding justice without regard to family or friends. Such people sometimes will behave as a 'jalma tan kena kinira' (have unpredictable manner) because they do not discriminate someone's dignity and the degree. However it does not mean that a firm stance to uphold a principle at a fixed price cannot be tolerated. In other words, the attitude of ora mingkuls still has a tolerance.

In Javanese ethics 'tegub' or ora mingkub means remains to be bending in seeing condition or circumstances, that in the concept of Javanese called ngerti empan papan (know how to put self). Ora mingkub in this matter refers to the notion that a person must possess teteg (steady), tatag (look forward), as well as firm or jejeg upright and sturdy. Such persons will sentosa ing budt, it means that not easily swayed in his establishment. The men are able to be protective, brave in justice because they can set the boost personal passions (bisa meper pepinginan). The people with this character will put forward the principle of ora mingksth, ora gumunan (not easy to admire something), and ora kagetan (not easily shocked in facing both bad things and the lure offered). For those, they should be able to set up the tive senses in a way of nutupi babahan hawa sanga which means closing 
all melik or bad desire and they should be able to be objective in looking at each event.

From the description above, it is clear that the values associated with the palace dances of the moral and ethical issues that are useful as forming a person's character is influenced by kadewasaning jiwa or maturity of the soul. Therefore, the Javanese people are required :

A. to be among (can understand other people, docile), amot (can accommodate people's opinions), momot (to handle trial, and gracefully)

B. to be religious, based on attitudes of mitubu and eling. Eling (remember to God, respect to teachers, parents, and others). Mitubu (faithful to God's commands).

C. to do social values with noble characters, sepi ing pamrib (do not expect any returns), friend (earnestly and always keep their promises), alus (soft), lana (consistent, true to the establishment), drana (hearted), sabar (patience), nrima (gracefully, accept God's gift), jatmika (any behavior based on rules of decency).

D. to keep moral values by being ririb (careful, introspective), rereh (patient, capable of self-restraint), rurub (calm), sumarab (resigned), lila legawa (sincere), and menep (self control, calm).

E. to implement the cultural values that are summarized in terms of empan papan (know how to put themselves), duga prayoga (careful, based on proper consideration), tepa slira (tolerance), mawas diri (introspection), mutual coopcration, and andhap asor (humble)

The core point of the palace dances value contains of a life framed by the wisdom and advices and they are packaged in the language of symbols in the form of dance, floor fatterns, accompaniment, dialogue, makeup and fashion. The philosophy of Joged Mataram includes various values of morality, spirituality, social, and religious. In terms of ethics-morality (moral values), it directs to the people to practice the sense, working out the heart in order to sharpen the sensibilities or responsiveness, to be able to well-behaved and intclligently control. Socio-cultural values include social teachings that are based on the unity and integrity, as well as social solidarity as implemented in everyday behavior. Thus, seen from the aspect of axiological, the palace dances contain 
of the teachings that put the 'sense' as 'spirit 'and 'restraint 'as a 'core'. Control of emotions is a basic aspect of the dances taught at the palace.

A lot of education can be obtained from a variety of palace dances. Adjustments with the times is very possible because of the many old values that are applied universally which means that almost all the tribes (ethnic) have similar beliefs, such as the existence of God the Almighty, have a sense of humanity, tolerance, unity, justice, mutual cooperation, deliberation which are really the collective agreement have all been covered in the principles of Pancasila as the basic values of Indonesia. Thus it is indeed that the palace dances are the 'dedication of life' (way of life) which are about mawas diri (introspection), tepa slira (tolerance), narima (accept God's gift), tatag (steadfastness), tough (immovableness), tanggap (quick response) manembah (devotion) to God, waspada (alert), ngati-ati (carefulness) which are in almost all parts of the world like Indonesia have those principle although in the different form and order.

Those values have contribution to the formation of national character. Through dance created, Hamengku Buwana I nurtured the values of 'satria tama' who always uphold honesty and willingness to sacrifice for the motherland and the people, so the philosophy of Joged Mataram can be applied anywhere because all knowledge contained in the concept of the dances actually leads to the doctrine of the perfection of life (kasampumaning urith) in the sense of devotion to others. By studying, living, and practicing the values of palace dances, it is expected to strengthen the national identity as a civilized nation, a nation that is able to solve the problems politely.

\section{J. Conglusion}

The study proved that the axiological aspects of Yogyakarta Palace dance contains teaching that puts the 'feel the spirit' and 'self-control' as the core. Self-control is based on 'feel', is an important aspect to form a noble character for the life of the nation. Thus, a palace dance 'is a dedication of life' (way of life) that can be used as a mean of education and cultivation of 
character. Many of the values embodied in the dance palace can function as forming characters that should be inculcated from childhood.

Various moral teachings and the bans veiled in the dance presentation should be dug up again, introduced and implemented to the public, including the values of mawas diri (introspection), tepa slira (tolerance), narima (acceptation of any gift from God), Tatag ( stoic), tangguh (immovable action), tanggap (quick understanding), manembah (worship) to God, waspada (alert), ngati-ati (carefulness). It is for sure that it needs further study which is adapted to the recent evolving paradigm. The adjustments with the times is very possible because many old values are universally applicable, meaning that almost all the trites (ethnic) have similar beliefs, such as on the existence of God the Almighty, the sense of humanity, tolerance, unity, justice, mutual cooperation, deliberation, and others with a mutual agreement that actually everything is summed up in the principles of Pancasila, as the state of Indonesia.

\section{DAFTAR PUSTAKA}

Bakker S.J., J.W.M.. $\quad$ 1984. Filsafat Kebudayaan, Yogyakarta: Kanisius. Brongtodiningrat, KRT. 1981 Falsafah Beksa Bedhaya sarta Beksa Srimpi ing

Ngayogyakarta dalam Kawruh Joged Mataram, Yogyakarta: Yayasan Siswa Among Beksa.

Endraswara, Suwardi. 2003. Mistik Kejawen: Sinkretisme, Simbolisme dan Sufisme dalam Budaya Spiritual Jawa. Yogyakarta: Narasi. 2010. Falsafah Hidup Jawa: Menggali Mutiara Kebijakan dari Intisari

Filsafat Kejawen. Yogyakarta: Cakrawala.

Geertz, Clifford.1976. The Interpretation of Culture. New York: Basic, Books, Inc.

Holt, Claire. 2000. Seni Di Indonesia: Kontinuitas dan Perwbaban, Teri. Soedarsono, RM, Yogyakarta: ISI.

Kaelan. 2010. Metode Penelitian Agama Kualitatif, Interdisipliner

Yogyakarta: Paradigma. 
Notonagoro, 1971 Pengertian Dasar bagi Pedoman Implementasi Pancasila untuk ABRI. Jakarta: Departemen Pertahanan dan Keamanan

Soedarsono, 1980 Beberapa Factor Penyebab Kemunduran Wayang Wong Gaya

Yogyakarta: Satu pengamatan Dari Segi Estetika Tari. Yogyakarta: Sub Bagian Proyek ASTT Yogyakarta.

Suryobrongto , G.B.P.H., 1981. dalam Fred Wibowo ed., Mengenal Tari Klasik

Gaya Yogyatearta: Dewan Kesenian Propinsi DIY

Suseno, Magnis, Frans, 1986 Etika Jawa: Sebuah Analisa Falsafi tentang Kebijaksanaan Hidup Jawa. Jakarta: Gramedia. . 1982. Tari Klasik Gaya Yogyakarta. dalam Kawrub Joged Mataram,

Yogyakarta: Dewan Ahli Yayasan Siswa Among Beksa Ngayogyakarta Hadiningrat.

Zalil, Abdul, Kyai 1830. Madu Tata Krami, Naskah koleksi pribadi KPH. Brongtodiningrat.

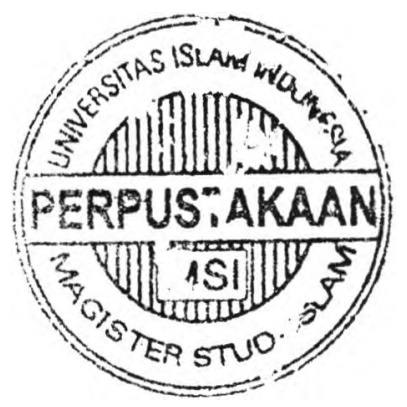

